\title{
Study of Subject and Object in Art Management
}

\author{
Ruiping Zhang and Lin Yu \\ College of Music ,Jiangxi University of Technology
}

Keywords: Art management; EQ of art management subject; Selection and use of artistic talent; Trend; Art management mechanism

\begin{abstract}
To further develop artistic productivity, people must perfect scientific management of the art, obtain vitality and benefit from management. The purpose of establishing art management suitable for the condition of China is to better organize and coordinate production of relevant artistic production departments in society, give full play to the enthusiasm, initiative and creativity of the majority of the artists, to promote the prosperity of socialism art cause and to create more and better quality spirit products to meet the needs of people's growing spiritual and cultural life. Art human resource management can be seen as modern personnel and labor management, it is the activities of plan, organization, motivation and control conducted in the aspects such as the obtaining, development maintenance and use of artistic human resources, which studies adjustment of human relations in organization, coordination of people and things to enrich and develop artistic human resources, excavate human potential, arouse people's enthusiasm, improve work efficiency and achieve theory, thinking, method and technique of organizational goals. Starting from art organizations' adaption to the change of living environment conditions, I study the development of subject and object management of China's art industry, combined with the discussion of current international enterprise human resource management as well as changes in enterprise human resource management in knowledge economy era, I analyze new model of art practitioners management suitable for our national conditions and actual situation of art industry in the future.
\end{abstract}

\section{Introduction}

Art management is a very comprehensive new discipline, which involves political economy, sociology, human science, law, management, psychology aspects, but it is not purely theoretical discussion, it is a very theoretical and practical application science. From $19^{\text {th }}$ century to the early $21^{\text {st }}$ century, with communication technologies like radio, television, film entering into artistic production field one after another, industrial, enterprise, independent new art production sector gradually formed, with the systematic, professional and social traditional artistic activities such as theater, cinema, dance as well as professional artistic creation, independent art department was formed, whether art management is scientific has major significance for prosperity of art.

I start from the viewpoint of "modern management science, art and psychology", taking human resources in art management as analysis object, taking study of subject and object in art management as thesis topic, the selected topic is from school basic teaching material: art management. The purpose of establishing and improving art management suitable for is to better organize and coordinate for Chinese national conditions is to better organize and coordinate production of every social artistic production sector, give full play to the enthusiasm, initiative and creativity of the 
majority of the artists, to promote the prosperity of socialism art cause and to create more and better quality spirit products to meet the needs of people's growing spiritual and cultural life.

My research approach and process are: early market research and data collection (including finding art and management books on the Internet, bookstores, libraries and survey in Hubei Provincial Museum and Wuhan Exhibition), then I clear up and analyze existing materials of Wuhan University of Technology master's degree thesis to find out regularity, further targetedly collect and perfect material, finally, I put forward some my own points of view for the current management status of Chinese art subject and art object, after exchanging with experienced art management persons, further improve specific points of art management. The technical route taken in study is to investigation - analysis and summary - practice - summary, namely to investigate and collect existing related cases data of art management, analyze and summarize the law of the data, put forward new ideas, then conduct experimental implementation to test whether the understanding is correct, so establish perfect, rational, scientific management system of art subject and art object. Specifically it is divided into four stages: (1) research and form construction of art management subject and object topics; (2) identify existing problems, creatively put forward tentative solutions about art subject and object management; (3) test program, eliminate errors, determine details; (4) select the best solution. Overall, from macro point of view, the paper gives analysis of after joining in the WTO, the impact of foreign art operating companies on China arts management, analyzes and presents six innovative trends of China's art subject and object management of knowledge economy and information society, which has some reference value for the development of China's artistic industry management; gradually definitely describes excavation, selection, training, use, incentive, assessment of artistic talents one by one, this paper puts forward four proposals on how to improve training effectiveness, describes the four aspects of artistic talents cultivation, this paper also sums up three ways how to make artistic talents operate efficient to give play to maximize potential: to introduce emotional intelligence theory into art management, preliminarily point out how to know and use artistic talents with emotional intelligence theory and point out EQ requirements for art management main body; detailedly describe type, quality and ability, function, organizational structure of art management subject and object; this paper puts forward seven recommendations on how to retain and attract talents; art management is an emerging interdiscipline, yet there is no complete system, I integrated knowledge of management, psychology and art, make macroscopic formation and microscopic detailed analysis on art subject management theory, put forward some concrete discussion and workable schemes, which has certain reference value for the development of China's art industry management.

\section{Art management research}

Artistic production is a kind of spiritual production, compared with material production, they have common points: they must have producers, production process and product. Now, products mostly circulate in the form of goods. But the differences are obvious: modern material production is socialized, modern mass production, its products must be standardized, while artistic production is mainly the individual labor of artists. Although comprehensive art like film, television, theater need cooperation of many artists, it is different from jobs on the assembly line done by workers. In art creation, artists should permeate their own thought, emotion, aspiration and ideals through the whole process of creative activity, reflect their own unique creation style and personality in their products, these will determine features of original creation, individuality, diversity and freedom of artistic 
production. Art products should not be standardized, inflexible and modeling, in addition, the management of artistic production activities must be different from the management of material production activities, they have their respective management principles, methods, measures, systems, they can not absolutely replace each other. Our country's art policy is implementing the "double hundred" policy, lead art in accordance with the law of artistic production.

Art is based on artistic phenomenon, it studies the law of art nature, art products, art creation, art appreciation and criticism, art exchange, art effect, art category, and comprehensively clarifies the nature and law of art. Such a subject should be positioned in the humanities, although involving natural science and social science, involving psychology, sociology, it is more closely associated with the culture.

Art management studies internal law of art management phenomenon, such as the particularity of system, function, goal, process, method, etc. of art management, this is the point to distinguish the two disciplines. Art management activities must comply with a series of art law revealed by art, therefore, art management inevitably establishes its own system based on the outcome of artistic research.

According to the characteristics that our country's art market covers wide range and has various forms, leading management system combined by hierarchical system and function system. The so-called hierarchical system is longitudinally divided into several levels to implement level management. For example, the art department, the Press and Publication Administration, Radio, Film and Television and National Heritage Board under the State Council are the highest management levels of the art market, they are responsible for formulating management principles, policies and relevant laws and regulations of art market and implementing macro-control management. The second level, people's government of every province, autonomous region and municipality sets up related departments and implements policies, laws and regulations of art market management formulated by the Central Committee of the Communist Party of China, formulates relevant laws and regulations of art market management combining with the specific circumstances of every province, autonomous region and municipality and carries out art market guidance for every province, autonomous region and municipality. The third level is that government of every district and county seriously implements policies, laws and regulations formulated by the Central Committee of the Communist Party of China and provinces and is responsible for the management and leadership of native area and county art market.

To further develop the course of art, people must solve fund problem, now fund of artistic institutions is mainly from financial investment, under the current national strength, it is unrealistic expect greater increase in financial investment in the coming years, therefore people must open up other capital source other than state investment. On the one hand, it requires the State to change the state of excessive low in art of the past, increase investment in construction as much as possible, reform irrational tax policy for enterprise and institutions, implement preferential regimes; on the other hand, to adopt approach of multi-channel and multi-form for financing to do the course of art.

Currently, it is important to solve two issues: 1. Distinguish art and art industry. For nonprofit art cause providing public goods, it should be really supported in place by the government, people must be willing to spend money when it should spend money, it should not be strong talk with little action, or even talk with no action; for operating art units (including some quasi operating art units), they should be pushed to the market firmly, not looking around, softhearted. 2. Take asset as link, according to market demand orientation, optimize and allocate artistic resource, actively develop 
multielement investors. (1) Increase strategic restructuring of the state-owned art department, enterprises and institutions, because the state-owned art department occupies China's artistic resource, including most part of human resources, it is China's art industry's dominant force. Doing well in reorganization, restructuring and transformation of state-owned arts sector, achieving optimal allocation of state-owned stock resource and change of production mechanism of art product is the key for speeding up the pace of art industry development. (2)Encourage non-state economic element and non-artistic nature unit participate in art industry, forming the pattern that public art cause and art industry lead, developing together with non-public art cause and art industry. For example, to encourage and support urban and rural collective and individual to set up a variety of artistic undertakings, promote enterprises and institutions to "supplement culture with culture", support non-art unit to establish art cause or invest in sectors, establish Development Fund, for the publicity of partial operating business like printing, distribution, advertising, people can also explore multielement investment and implement company operation to positively encourage social capital contribution, for public welfare art course, government should formulate reasonable tax policy and take favorable measures of provide naming rights and other incentives to encourage all walks of life in society and foreign capital to enthusiastically donate. In short, policy can be a little wide and a little flexible, which can make up serious shortage of state financial allocation funds.

The subjects of art management are art managers and their higher authorities of their organizations, for example, managers of Capital Museum are made up of curator, deputy curator, Party head branch secretary, committee of experts. Art management subject of the new era needs to help the growth and development of art industry with forward-looking strategic vision, which requires managers to have higher comprehensive quality. At present, the critical knowledge and ability that the Chinese art human resources managers should possess are:

(l) having good sociability skills, be able to listen and understand other people's ideas and requirements;

(2) having higher artistic training and language expression ability;

(3) having coordination and problem-solving abilities (i.e. coordination employee relation);

(4) be able to use statistical techniques to elaborate labor and related conditions;

(5) having regulatory knowledge (such as labor law, the Employment Standards Act and related regulations);

(6) the ability to lead (i.e. to guide and train managers of each levels to constructively do work well instead of doing everything himself personally; to fully mobilize enthusiasm of each creator and the entire unit);

(7) be familiar with the company conditions, know the development strategic objectives of art industry and needs of art market very well, participate in goal-formulating work of art function departments.

The management ability of art managers is not born, but acquired in learning and working practices.

The specific work of art managers is included in practical work such as plan and implementation of different types of painting and calligraphy art institutions, places and painting and calligraphy exhibitions, including exhibitions, auction project plan, market promotion and marketing, public relation, purchase and sale of works of art, management work of artist and agency personnel, etc. All the functions of art human resource management can be summarized as art human resource allocation (including planning, recruitment, selection, recruitment, deployment, promotion, demotion, 
rotation, etc. of art human resource), training and development (skill training, potential development, profession career management, organization learning, etc.), wages and benefits (remuneration, incentives, etc.) and institution construction (organization design, job analysis, employee relation, employee involvement, personnel administration, etc.) of four categories. This four categories of function gradually formed and perfect in management development process, with the change of the external business environment of art industry as well as development of social special advisory service industry, these functions will differentiate again, one part of them will transfer to socialized industry management service network. Managing four categories of function activities is a means of art industry to achieve its business objectives, art industry can differentiate and combine these means again in accordance with the need of its business in order to achieve optimum management in particular environment, which can often be seen in management practice.

Today, as science and technology become more and more developed, EQ demand for art managers is increasingly high. Gallery managers need to face subordinates with different characters, different abilities and different needs, superiors and subordinates often need to exchange and coordinate feeling, in the sale of works of art, they need to carefully watch what customers are doing and saying, if EQ is low, one's work will never be good.

EQ (EMOT10NALQAULITY EQ for short) is corresponding to IQ (INTELLEGNECEQUOTIENT QI for short), if people say how high the IQ is, it refers to the individual level of intelligence, EQ refers to the character and emotion tolerance degree of a person. Humans should at least have the following seven different intelligences: verbal intelligence, mathematical logic intelligence, spatial intelligence, musical intelligence, physical intelligence, interpersonal intelligence and self-knowing intelligence. EQ is closely related with interpersonal intelligence and self-knowing intelligence, Professor of psychology of Harvard University Gardner thought: interpersonal intelligence is "be able to recognize other's mood, temperament, motivation, desire, etc., and to make appropriate reaction"; self-knowing intelligence is "be able to recognize one's own feeling, identify the similarities and differences and take as a basis to act", the EQ level can reflect both intelligence. People with high QI can win high scores in the professions, while people with high EQ can produce good results in the management operation, so in modern management, managers should learn more knowledge about EQ, QE can be improved through training.

Attracting talents is the first step of talent management, it is also a very important step, then raising talents would be easier, using talents would be with facility, remaining talents would also be convenient. The channels of attracting talents can be varied: recommended by the "acquaintance" or "professional organization"; attracting talents through advertising is a commonly used method by countries, of which the advantages are that information diffusion is large, alternate ratio is large, blindness is reduced; recommended by the same industry or participating in large talent exchange; supply and demand meeting held at the university campus; network recruiting and other channels. Good mechanism and social environment should be created and relevant policies should be formulated to provide talents conditions for displaying their aspirations, as an old saying that faith will move mountains to open. It should change from providing job opportunities in the past to provision of a career and not just a job, focus on publicity of talents' growing in the company; it should change from thinking of recruitment when lacking certain talents in the past to introducing talents for work need, talents reservation and propaganda of art industry, which is forward-looking, never "waiting the rice into the pot"; it should change from valuing education background, 
profession focusing on the use to value personal qualities, abilities and focusing on the future profession cultivation when selecting talents. To help talents draft growth plan in the company, point out shortcut of rapid growth and provide detailed horizontal and vertical training programs, so that the knowledge structure of talents is more reasonable and constantly updated, give full play to its potential in his career; only by this, "Planting Chinese parasol, attracting phoenix".

Strengthen the legal system construction of art management to protect the legitimate rights and interests of art organizations, so that workers with low quality will have no chance. Innovate mechanism of using, fully reflect the situation that able person should do more work, working person should gain more, common person do not work, person without morality and ability leave his position. Establish and continuously improve organizational system, systemize the discovery, development, employment, evaluation of talents, including flexible personnel employment system; scientific, fair, operational evaluation system; effective incentive mechanism; fair and equitable promotion system, etc. to ensure talent showing itself. For example: Xuzhou city perfects artistic talent incentive policy, establishes a performance-oriented personnel value, in the aspects such as title appraisal, achievement award, job evaluation, housing, break boundaries of education background and qualification, take innovation ability, innovation research results and actual operating management performance as the main criterion, establish incentive mechanism, encourage more fine works and more excellent talents; increase publicity of art celebrity, news media establishes special topic or column to introduce literature artist of Xuzhou origin or having worked and lived in Xuzhou as planned to create good social atmosphere for cultivation and growth of artistic talents. Suzhou city cultural publicity work leading group specially issued "Opinions on attracting excellent culture and art talents to come Suzhou city to do pioneering work", with the employing concept of "not require where the talents are from, but require what the talents are used for", implementing a more open talents policy, encouraging flexible flow of excellent talents, trying to introduce excellent talents and providing talents guarantee for the construction of better culture city. "Flexibility" principle is mainly manifested in: first, by a flexible flow approach. Excellent talents coming to Suzhou for doing pioneering work can sign employment contract with employer in accordance with law, or sign working project agreement to determine rights and obligations of both parties. Second, excellent talents come to Suzhou to work, they can work in Suzhou for long-term, or they can come to Suzhou to workat regular intervals or irregular schedule each year without changing any relationship, according to their will. Third, excellent talents can undertake Suzhou City artistic and cultural projects in places outside of Suzhou, implementing remote services. Fourth, excellent talents can negotiate with employer to determine ways to provide other services more conducive to both sides.

The cause of art should formulate for their talents work goals slightly higher than their actual ability, motivate them to challenge themselves, surpass themselves so as to achieve the best use of their ability, suitable talents for suitable use. When talent completes challenging work one after another, he realized the value of his own, the cause of art will get maximum benefit.

In order to retain talented employees, US Hanigan company implements employee structure diagram mode, do satisfaction coordinates: one axis reflects employees' satisfaction for job, the other axis reflects employees' satisfaction for the company, in this way, Hanigan company monitors the possibility of employees' leaving the company, helps employees pass job-hopping danger period. For some employees who can be promoted, at a time when there is no position vacancy, the company lets the employees to hold the post of special a task that requires several months to complete, employees 
will feel guilty if they leave office suddenly in a noticeable work project, this will win a few months respite for the department, finding promotion post suitable for employees' expectation.

\section{Conclusions}

Art management is an emerging interdiscipline, yet there is no complete system, I integrated knowledge of management, psychology and art, make macroscopic formation and microscopic detailed analysis on art subject management theory, put forward some concrete discussion and workable schemes, which has certain reference value for the development of China's art industry management. Art managers will learn from their own management methods and shortage of mechanism and ignored details, thereby improving human resource management practices, improving management efficiency, activating creative enthusiasm of employees and promoting the development of the art sector. The four management system of art management subject multielement cross makes art organizations of different natures adopt unique methods, first of all, distinguish art institution with operating units, management of gallery and symphony orchestra inevitably has different focus with private galleries and brokerage firms. This paper still lacks in-depth discussion for personalities of art object management under different systems, in the future, study of art object management will follow the framework of this thesis, on the basis of the study having been completed, do survey, summary and analysis respectively for their management strategy and characteristics.

\section{Acknowledgement}

Jiangxi province artistic planning issue: " Feasibility study of Jiangxi private performing market industrial operation - Taking Nanchang New Central Plains Theatre as a case" Project Item Number: YZ2014081

\section{References}

[1] Design marketing and management, Chen Hanqing, Yin Dingbang, Shao Hua, Hunan Science and Technology Press 2020.9

[2] Magic emotion IQ, chief editor Hai Yunming, China City Press, 1997

[3] EQ Daniel Goleman (aiel.Golela), translated by Zhang Meihui, Times Press (Taiwan) 19\%

[4] How foreign companies retain talents, aragonite business management 2000

[5] Scientific management and management science, Hui Yimin, Lin Kuanming, Science and Technology Literature Publishing House 199 lst edition of July

[6] Management psychology and art of leadership, Liu Peisen, Chongqing University Press 1988. 1201 page

[7] Modern psychology theory and application, Zhu Baorong, Shanghai People's Publishing House 2020.67 page

[8] Talking about singing, Li Ling, Shanghai People's Publishing House page 29

[9] Successful art of leadership: mutual encouragement theory, Cha Puman, Beijing China Business Press 1989.9 O page 
[10]Beauty of creation: product design art and culture, Li Yanzu, Chinese People's University Press, 2000 